\title{
RESEARCH
}

Open Access

\section{Neuroinflammation and amyloid-beta 40 are associated with reduced serotonin transporter (SERT) activity in a transgenic model of familial Alzheimer's disease}

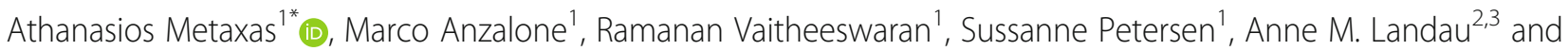
Bente Finsen ${ }^{1}$

\begin{abstract}
Background: Discrepant and often contradictory results have accumulated regarding the antidepressant and procognitive effects of serotonin transporter (SERT) antagonists in Alzheimer's disease.

Methods: To address the discrepancy, we measured the activity and density of SERT in the neocortex of 3-24month-old APP swe $_{\text {PSS }} 1_{\mathrm{dEg}}$ and wild-type littermate mice, by using $\left[{ }^{3} \mathrm{H}\right] \mathrm{DASB}$ autoradiography and the $\left[{ }^{3} \mathrm{H}\right] 5-\mathrm{HT}$ uptake assay. Levels of soluble amyloid- $\beta(A \beta)$, and pro-inflammatory cytokines that can regulate SERT function, such as interleukin-1 $\beta$ (IL-1 $\beta$ ), interleukin-6 (IL-6), and tumor necrosis factor (TNF), were measured in parallel. Neuroinflammation in aging $A P P_{\text {swe }} / P S 1_{\text {dEg }}$ mice was further evaluated by $\left[^{3} \mathrm{H}\right] \mathrm{PK} 11195$ autoradiography.

Results: Decreased SERT density was observed in the parietal and frontal cortex of 18-24-month-old APP swe $_{\text {SPS1 }}$ dE9 $_{1}$ mice, compared to age-matched, wild-type animals. The maximal velocity uptake rate $\left(V_{\max }\right)$ of $\left[{ }^{3} \mathrm{H}\right] 5-\mathrm{HT}$ was reduced in neocortical preparations from 20-month-old transgenic vs. wild-type mice. The reduction was observed when the proportion of soluble $A \beta_{40}$ in the $A \beta_{40 / 42}$ ratio increased in the aged transgenic brain. At concentrations compatible with those measured in 20-month-old $A P P_{\text {swe }} / P S 1_{\mathrm{dEg}}$ mice, synthetic human $A \beta_{40}$, but not $A \beta_{42}$, reduced the baseline $V_{\max }$ of $\left[{ }^{3} \mathrm{H}\right] 5-\mathrm{HT}$ by $\sim 20 \%$. Neuroinflammation in $A P P_{\text {Swe }} / P S 1_{\mathrm{dEg}}$ vs. wild-type mice was evidenced by elevated $\left[{ }^{3} \mathrm{H}\right]$ PK 11195 binding levels and increased concentration of IL-1 $\beta$ protein, which preceded the reductions in neocortical SERT density and activity. Age-induced increases in the levels of IL-1 $\beta$, IL-6, and TNF were observed in both transgenic and wild-type animals.

Conclusions: The progression of cerebral amyloidosis is associated with neuroinflammation and decreased presynaptic markers of serotonergic integrity and activity. The $A \beta_{40}$-induced reduction in the uptake kinetics of $\left.{ }^{3} \mathrm{H}\right] 5-\mathrm{HT}$ suggests that the activity of SERT, and potentially the effects of SERT antagonism, depend on the levels of interstitial $A \beta_{40}$.
\end{abstract}

Keywords: Alzheimer's disease, APP swe $/ P S 1_{\mathrm{dE} 9}$, Amyloid-beta, SSRIs, Serotonin transporter, DASB, Neuroinflammation, TSPO, Cytokines

\footnotetext{
* Correspondence: ametaxas@health.sdu.dk

'Department of Neurobiology, Institute of Molecular Medicine, University of

Southern Denmark, J.B. Winsløws Vej 25, DK-5000 Odense C, Denmark

Full list of author information is available at the end of the article
}

(c) The Author(s). 2019 Open Access This article is distributed under the terms of the Creative Commons Attribution 4.0 International License (http://creativecommons.org/licenses/by/4.0/), which permits unrestricted use, distribution, and reproduction in any medium, provided you give appropriate credit to the original author(s) and the source, provide a link to the Creative Commons license, and indicate if changes were made. The Creative Commons Public Domain Dedication waiver (http://creativecommons.org/publicdomain/zero/1.0/) applies to the data made available in this article, unless otherwise stated. 


\section{Background}

The discussion surrounding the effectiveness of selective serotonin reuptake inhibitors (SSRIs) in Alzheimer's disease (AD) and related dementias has extended beyond the drugs' effects on comorbid depression [1]. Clinical studies on the incidence of dementia have reported an increased risk of cognitive impairment following SSRI treatment [2], but also beneficial delays in the conversion from mild cognitive impairment to $\mathrm{AD}$ [3]. In preclinical studies, the chronic administration of SSRIs to transgenic models of $\mathrm{AD}$ may improve cognitive performance $[4,5]$, but also increases mortality rates compared to vehicle administration $[6,7]$. The reasons for the heterogeneity in the antidepressant and cognitive effects of SSRIs in AD remain unknown.

The serotonin transporter (SERT) is the primary target of SSRI treatment [8]. By blocking SERT, SSRIs inhibit the clearance of extracellular serotonin (5-HT) and potentiate serotonergic neurotransmission. There is evidence to suggest that the brain levels of SERT change dynamically with $\mathrm{AD}$ progression. The binding of $\left[{ }^{3} \mathrm{H}\right]$ escitalopram is higher than control levels in the cortex and hippocampus of 4-month-old $A P P_{\mathrm{swe}} / P S 1_{\mathrm{dE} 9}$ mice [9], a model of familial AD harboring mutations in the amyloid precursor protein $(A P P)$ and presenilin-1 (PSEN1; PS1) genes [10]. In the hippocampus of 3xTg-AD mice, a model of combined amyloidosis and tauopathy, elevated SERT immunoreactivity has been observed by 3 months of age, i.e., prior to the manifestation of amyloid- $\beta$ (A $\beta)$-induced memory impairment or the deposition of plaques [11, 12]. These "early" increases in the density of SERT, which may decrease the level of extracellular $5-\mathrm{HT}$, contrast the degenerative reductions in the levels of several serotonergic components, including SERT, which are typically observed in the brain of aged amyloidosis models [13, 14] and advanced cases of $\mathrm{AD}$ [15]. The aforementioned literature implies that a low serotonergic tone may be associated with both increased and decreased SERT-binding levels, according to disease stage. Thus, it is plausible that the therapeutic efficacy of SSRIs will vary considerably during the course of $\mathrm{AD}$, depending on the density and/or activity of the SERT.

Chronic, low-grade neuroinflammation constitutes hallmark AD pathology [16]. Neuroinflammation has been demonstrated in the brain of living demented patients and models of AD by molecular imaging of the translocator protein (TSPO), which is primarily a marker of microgliosis [17]. The neuroinflammatory reaction is characterized by increased microglial production of inflammatory cytokines, such as interleukin-1 beta (IL-1 $\beta$ ) and tumor necrosis factor [TNF [18, 19]]. Moreover, IL-1 $\beta$, TNF, and interleukin-6 (IL-6) are elevated in the periphery of $\mathrm{AD}$ patients compared to non-AD subjects
[20]. Interestingly, these pro-inflammatory cytokines have been reported to alter SERT function in a cytokine-specific manner. In the mouse midbrain and striatum, IL-1 $\beta$ can stimulate SERT activity, by decreasing the apparent Michaelis constant $\left(K_{\mathrm{m}}\right)$ of the transporter for 5-HT [21]. In neuronal cell lines and mouse synaptosomal preparations, TNF decreases $K_{\mathrm{m}}$ and increases the apparent maximal velocity rate $\left(V_{\max }\right)$ of 5-HT uptake [22]. Unlike the stimulating effects of IL- $1 \beta$ and TNF, treatment with IL- 6 reduces the mRNA and protein levels of SERT in the mouse hippocampus [23]. These data are indicative of a cytokine-induced mechanism for the dysregulation of SERT, which could interfere with serotonergic neurotransmission during the course of AD.

In the present study, SERT density and function were evaluated in parallel with markers of neuroinflammation in the brain of aging $A P P_{\mathrm{swe}} / P S 1_{\mathrm{dE} 9}$ mice. It was hypothesized that the progression of amyloidosis would be associated with age-related alterations in the binding levels of SERT, which could be attributed to increased levels of specific neuroinflammatory markers.

\section{Materials and methods}

Animals

A total of $113 A P P_{\text {swe }} / P S 1_{\mathrm{dE} 9}$ transgenic (TG) and littermate wild-type (WT) control mice were used in this study (109 females; 4 males). The animals were bred and maintained on a C57BL/6J background in the Biomedical Laboratory of the University of Southern Denmark. Mice were group-housed in a temperature $\left(21 \pm 1^{\circ} \mathrm{C}\right)$ and humidity (45-65\%) controlled environment, under a 12/12-h light/dark cycle (lights on: 7 am), with free access to food and water.

\section{$\left[{ }^{3} \mathrm{H}\right]$ DASB and $\left[{ }^{3} \mathrm{H}\right] \mathrm{PK} 11195$ autoradiography}

Animals were euthanized by cervical dislocation at 3 , $6,12,18$, and 24 months of age $(n=6 /$ group, total number $=60$ ). The brains were immediately removed, placed on a petri dish containing ice, and bisected along the midline. The brainstem from the left hemisphere was frozen on dry ice and used for measuring Scl6a4 (Sert) mRNA levels by reverse transcription quantitative real-time polymerase chain reaction (RT-qPCR). The right brain hemisphere was immersed for $2 \mathrm{~min}$ in isopentane on dry ice $\left(-30^{\circ} \mathrm{C}\right)$ and used for autoradiography. Consecutive, $20-\mu \mathrm{m}$-thick sagittal sections were collected on ice-cold SUPERFROST $\mathrm{T}^{\mathrm{TM}}$ slides at $300 \mu \mathrm{m}$ intervals, by using a Leica CM3050S cryostat (Nussloch, Germany). The sections were dried overnight at $4{ }^{\circ} \mathrm{C}$ in a box containing silica gel and stored at $-80^{\circ} \mathrm{C}$ until use.

$\left[{ }^{3} \mathrm{H}\right] \mathrm{DASB}$ autoradiography was used to measure the density of SERT, as described previously [24]. Sections 
were thawed at room temperature (RT) and prewashed in 50-mM Tris- $\mathrm{HCl}$ buffer ( $\mathrm{pH} 7.4$ ), containing $150 \mathrm{mM}$ $\mathrm{NaCl}$ and $5 \mathrm{mM} \mathrm{KCl}(3 \times 15 \mathrm{~min})$. The sections were subsequently incubated for $2 \mathrm{~h}$ in the same buffer, containing $1 \mathrm{nM}\left[{ }^{3} \mathrm{H}\right]$ DASB (specific activity $80 \mathrm{Ci} / \mathrm{mmol}$; ART1523, American Radiolabeled Chemicals, Inc.). To determine non-specific binding (NSB), adjacent sections were radiolabeled with $1 \mathrm{nM}\left[{ }^{3} \mathrm{H}\right] \mathrm{DASB}$ in the presence of $10 \mu \mathrm{M}$ paroxetine $\mathrm{HCl}$ hemihydrate (P9623; SigmaAldrich). Incubations were terminated by three 1-min washes into ice-cold 50-mM Tris-HCL buffer ( $\mathrm{pH} 7.4$ ), followed by a rapid rinse in ice-cold deionized $\mathrm{H}_{2} \mathrm{O}$ $\left(\mathrm{dH}_{2} \mathrm{O}\right.$, Ultra-Clear; Siemens).

$\left[{ }^{3} \mathrm{H}\right] \mathrm{PK} 11195$ autoradiography was used to measure the density of the neuroinflammatory marker TSPO [25]. Sections were thawed at RT and prewashed in $50-\mathrm{mM}$ Tris- $\mathrm{HCl}$ buffer (pH 7.4), containing $150 \mathrm{mM}$ $\mathrm{NaCl}, 5 \mathrm{mM} \mathrm{KCl}, 1.5 \mathrm{mM} \mathrm{MgCl}_{2}$, and $1.5 \mathrm{mM} \mathrm{CaCl}_{2}$. Incubations were carried out for $2 \mathrm{~h}$ in the same buffer, containing $3 \mathrm{nM}\left[{ }^{3} \mathrm{H}\right] \mathrm{PK} 11195$ (specific activity $82.7 \mathrm{Ci} /$ mmol; NET885, PerkinElmer). NSB was determined in the presence of $10 \mu \mathrm{M}$ unlabeled PK11195 (C0424; Sigma-Aldrich). The incubations were terminated as described for $\left[{ }^{3} \mathrm{H}\right]$ DASB.

The labeled sections were dried for $2 \mathrm{~h}$ under a stream of cold air and placed against Carestream ${ }^{\circ}$ Kodak $^{\circ}$ BioMax MR film for a period of 25 days. To allow quantification, ${ }^{3} \mathrm{H}$ microscales of known radioactive concentration were also apposed to each film (American Radiolabeled Chemicals, Inc.). After development with KODAK substitute D-19 developer (TED PELLA, Inc.), images were digitized using a white sample tray and the Coomassie Blue settings on a ChemiDoc ${ }^{\text {ma }}$ MP imaging system (BIO-RAD). Values of specific binding were calculated by subtracting the level of non-specific from total binding levels, using ImageJ software (v1.50e; National Institutes of Health, MD, USA). For each animal, specific binding in the frontal, parietal, occipital, and temporal cortices was analyzed on 2-6 consecutive sections, by reference to the Allen Mouse Brain Atlas for sagittal sections [26].

\section{Sert RT-qPCR}

Trizol ${ }^{\circ}$-isolated RNA $(2 \mu \mathrm{g})$ from the brainstem of 3-, 6-, 12-, 18-, and 24-month-old TG and WT mice was reverse-transcribed to cDNA with the Applied Biosystems $^{\text {тx }}$ high-capacity cDNA transcription kit (Thermo Fisher Scientific). Samples of $20 \mu \mathrm{L}$ were run in triplicate on a StepOne-Plus ${ }^{\text {Th }}$ Real-Time PCR system (Applied Biosystems $^{\text {tm }}$, Thermo Fisher Scientific). Each sample contained nuclease-free $\mathrm{H}_{2} \mathrm{O}$ (Thermo Fisher Scientific), $1 \times$ Maxima SYBR green/probe master mix (Thermo Fisher Scientific), $500 \mathrm{nM}$ forward and reverse primers (TAG Copenhagen A/S), $5 \times$ diluted cDNA for Sert, and 10x diluted cDNA for hypoxanthine phosphoribosyltransferase $(H p r t)$, which was used as a reference gene. Primer sequences for Hprt and Sert have been described previously [24, 27]. After normalization to $\mathrm{Hprt}$, data were expressed as fold-change from the mean Sert/Hprt ratio of 3-month-old WT mice. Nuclease-free $\mathrm{H}_{2} \mathrm{O}$ and genomic DNA instead of cDNA were used to control for contamination.

\section{$\left[{ }^{3} \mathrm{H}\right] 5-\mathrm{HT}$ transport assay}

The assay was performed as detailed previously [22], using freshly isolated cortical tissue from a female, 3-, 6-, 12-, and 20-month-old, WT and TG mice $(n=5-7 /$ group, total number $=49$ ). Freshly prepared homogenates were required for the assay, as preparations of frozen material led to undetectable levels of specific binding.

Cortices were homogenized in $10 \mathrm{vol}(w / v)$ of ice-cold HEPES $(10 \mathrm{mM}) /$ sucrose $(0.32 \mathrm{M})$ buffer ( $\mathrm{pH} 7.4)$, by using a motor-driven, Teflon-glass tissue grinder at 800 rpm (Wheaton Instruments). The homogenate was centrifuged for $10 \mathrm{~min}$ at $1000 \times \mathrm{g}$ in a refrigerated centrifuge $\left(4{ }^{\circ} \mathrm{C}\right.$; RC M150 GX, Sorvall). The pellet was discarded, and $200 \mu \mathrm{L}$ of the supernatant (S1) kept on ice for determining the levels of IL- $1 \beta$, IL- 6 , TNF, and $A \beta_{40 / 42}$ by Meso Scale Discovery immunoassays. The S1 supernatant was transferred to clean tubes and centrifuged at $100,000 \times g$ for $20 \mathrm{~min}\left(4^{\circ} \mathrm{C}\right)$. The resulting pellet was suspended in $10 \mathrm{mM}$ HEPES buffer ( $\mathrm{pH}$ 7.4), containing $130 \mathrm{mM} \mathrm{NaCl}, 1.3 \mathrm{mM} \mathrm{KCl}, 2.2 \mathrm{mM} \mathrm{CaCl}, 1.2 \mathrm{mM}$ $\mathrm{MgSO}_{4}, 1.2 \mathrm{mM} \mathrm{KH_{2 }} \mathrm{PO}_{4}, 1.8 \mathrm{~g} / \mathrm{l}$ glucose, $100 \mathrm{mM}$ pargyline, and $100 \mathrm{mM} \mathrm{L}$-ascorbic acid (assay buffer). Total protein concentration was determined with a Pierce ${ }^{\mathrm{Tx}}$ BCA protein kit (Thermo Fisher Scientific).

The membrane suspension was pre-incubated for 10 min at $37^{\circ} \mathrm{C}$ in a BINDER shaking incubator (BFD53; VWR). Incubations were carried out for $5 \mathrm{~min}$ at $37^{\circ} \mathrm{C}$, using six concentrations of $1.0 \mathrm{Ci} / \mathrm{mmol}\left[{ }^{3} \mathrm{H}\right] 5-\mathrm{HT}(20$ $\mathrm{nM}-2.5 \mu \mathrm{M})$, which was prepared by diluting the specific activity of stock $\left[{ }^{3} \mathrm{H}\right] 5-\mathrm{HT} \quad(76.3 \mathrm{Ci} / \mathrm{mmol}$; NET1167, PekinElmer) with unlabeled 5-HT (\#14927; Sigma-Aldrich). The final assay volume was $200 \mu \mathrm{L}$, composed of $160 \mu \mathrm{L}$ freshly prepared membrane suspension, $20 \mu \mathrm{L}$ assay buffer, and $20 \mu \mathrm{L}$ of $\left[{ }^{3} \mathrm{H}\right] 5-\mathrm{HT}$ in assay buffer. Specific uptake was defined as total uptake minus uptake in the presence of $10 \mu \mathrm{M}$ paroxetine $\mathrm{HCl}$ hemihydrate. Under these conditions, maximally observed radioligand depletion was $14 \%$ at $20 \mathrm{nM}\left[{ }^{3} \mathrm{H}\right] 5-\mathrm{HT}$. The reactions were stopped by vacuum filtration through Whatman GF/B filters, pre-soaked for $1 \mathrm{~h}$ in $0.1 \%$ polyethylenimine. The filters were washed three times with $3 \mathrm{~mL}$ of ice-cold assay buffer ( $\mathrm{pH} 7.4$ ), all procedures carried out using a 48-well Brandel harvester. Filter disks were placed in $5 \mathrm{~mL}$ scintillation liquid (Optiphase Hisafe 3; PerkinElmer) and shaken vigorously. Following 
overnight equilibration, bound radioactivity was measured in a Tricarb 2910 TR liquid scintillation counter (PerkinElmer) for $5 \mathrm{~min} /$ sample.

To determine the effects of $A \beta$ on the kinetics of $\left[{ }^{3} \mathrm{H}\right] 5-\mathrm{HT}$ transport, membranes isolated from the forebrain of 3-month-old wild-type animals $(n=4)$ were incubated with increasing concentrations of $\left[{ }^{3} \mathrm{H}\right] 5-\mathrm{HT}$ as described above, in the presence or absence of $100 \mathrm{nM}$ lyophilized trifluoroacetate salts of synthetic human $A \beta_{40}$ (\#03138; Invitrogen) and $A \beta_{42}$ (\#03112; Invitrogen). These peptide concentrations were based on the levels of soluble $A \beta$ measured in the S1 supernatant from the brain of 20 -month-old $A P P_{\text {swe }} / P S 1_{\mathrm{dEg}}$ mice by Meso Scale Discovery. $A \beta$ was dissolved in assay buffer and added to the incubation mixture immediately before the 10-min pre-incubation period of the membrane suspension.

\section{$\left[{ }^{3} \mathrm{H}\right] \mathrm{DASB}$ inhibition assay}

The ability of increasing concentrations of $A \beta_{40}$ and $\mathrm{A} \beta_{42}(0.01 \mathrm{pM}-10 \mu \mathrm{M})$ to displace the binding of $2 \mathrm{nM}$ $\left[{ }^{3} \mathrm{H}\right]$ DASB was examined in forebrain preparations from 3-month-old WT mice. Peptides were dissolved in 50 $\mathrm{mM}$ Tris- $\mathrm{HCl}$ buffer (pH 7.4), containing $150 \mathrm{mM} \mathrm{NaCl}$ and $5 \mathrm{mM} \mathrm{KCl}$ (incubation buffer). Incubations were carried out at RT for $2 \mathrm{~h}$, in a final volume of $200 \mu \mathrm{L}$, composed of $160 \mu \mathrm{L}$ membrane suspension, $20-\mu \mathrm{L}$ incubation buffer with or without $A \beta$, and $20 \mu \mathrm{L}$ of $\left[{ }^{3} \mathrm{H}\right]$ DASB in incubation buffer. NSB was determined in the presence of $10 \mu \mathrm{M}$ paroxetine $\mathrm{HCl}$ hemihydrate. The procedure for terminating incubations and processing the GF/B filters was as described for the $\left[{ }^{3} \mathrm{H}\right] 5-\mathrm{HT}$ transport assay.

Meso Scale Discovery analysis of IL- $1 \beta$, IL- 6 , TNF, and A $\beta$ The concentration of IL-1 $\beta$, IL- 6 , and TNF in the S1 supernatant from the cortices of 3-, 6-, 12-, and 20-month-old WT and TG mice was determined with a custom-designed V-PLEX mouse pro-inflammatory kit, according to manufacturer instructions (K152AOH-2; Meso Scale Diagnostics, LLC). Levels of soluble $A \beta_{42}$ and $A \beta_{40}$ in the S1 supernatant were measured with the V-PLEX A $\beta$ peptide kit (K15200E-2; Meso Scale Diagnostics, LLC). Plates were processed in a SECTOR ${ }^{\circ}$ Imager 6000 plate reader (Meso Scale Diagnostics, LLC), and data acquired with Discovery Workbench software (v4.0; Meso Scale Diagnostics, LLC). Results are presented as pg of protein/mg of total protein, the latter determined with a Pierce ${ }^{\mathrm{m} m}$ BCA protein kit, and bovine serum albumin as standard (Thermo Fisher Scientific).

\section{Experimental design and statistical analysis}

Parametric statistics were employed, following an inspection of the data for normality with the KolmogorovSmirnov test. Values of specific $\left[{ }^{3} \mathrm{H}\right] \mathrm{DASB}$ and $\left[{ }^{3} \mathrm{H}\right]$ PK11195 binding were determined in six consecutive sections containing the frontal, parietal, and occipital cortices, and two consecutive sections containing the temporal cortex, from a total number of $60 A P P_{\text {swe }} /$ $P S 1_{\mathrm{dE} 9}$ TG and WT control mice ( $n=6 /$ group). A three-way ANOVA for the independent factors age, genotype, and brain region was used to analyze the autoradiography results. The effects of age and genotype on the binding of $\left[{ }^{3} \mathrm{H}\right] \mathrm{DASB}$ and $\left[{ }^{3} \mathrm{H}\right] \mathrm{PK} 11195$ were further examined in individual brain regions by using partial two-way ANOVAs. Where ANOVA yielded significant effects, between-group differences were explored by Bonferroni multiple comparison post hoc tests. A percentage change from WT control binding levels of $\left[{ }^{3} \mathrm{H}\right]$ DASB and $\left[{ }^{3} \mathrm{H}\right]$ PK11195 was calculated for each group of TG mice. These values were used to study the association between age-related changes in the density of SERT and TSPO in TG animals, by using the Pearson product-moment correlation. For the $\left[{ }^{3} \mathrm{H}\right] 5-\mathrm{HT}$ transport assay, the values obtained from 3 to 4 independent experiments were pooled and analyzed by using the Michaelis-Menten equation built into GraphPad Prism (v5.0; GraphPad Software, Inc.). The apparent $V_{\max }$ and $K_{\mathrm{m}}$ values were compared between groups of aging WT and TG animals by using two-way ANOVA, followed by Bonferroni post hoc comparisons. $V_{\max }$ and $K_{\mathrm{m}}$ values of $\left[{ }^{3} \mathrm{H}\right] 5$-HT uptake in the presence and absence of soluble $A \beta_{40 / 42}$ were derived from 3 independent experiments and compared by two-tailed independent $t$ tests. A two-way ANOVA, followed by Bonferroni posttests, was used to examine the effects of age and genotype on the levels of Sert, TNF, IL-1 $\beta$, IL-6, A $\beta_{40}$, and $\mathrm{A} \beta_{42}$. Throughout all experiments, samples from $A P P_{\mathrm{swe}} / P S 1_{\mathrm{dE} 9} \mathrm{TG}$ and WT control groups were processed in parallel. Significance was set at $\alpha \leq 0.05$, and the ANOVAs performed using Statistica ${ }^{\text {TM }}$ software (v10; TIBCO Software, Inc.). Values are presented as the mean \pm standard error of the mean (SEM) of $n$ replicates/experiment.

\section{Results}

SERT density is decreased in the neocortex of aging $\mathrm{APP}_{\text {swe }} / \mathrm{PS} 1_{\mathrm{dE}}$ mice

$\left[{ }^{3} \mathrm{H}\right]$ DASB was used to measure the density of SERT in brain sections prepared from 3-, 6-, 12-, 18-, and 24-month-old $A P P_{\mathrm{swe}} / P S 1_{\mathrm{dE}}$ TG and WT control animals ( $n=6 /$ group). Quantification of specific $\left[{ }^{3} \mathrm{H}\right] \mathrm{DASB}$ binding revealed reduced SERT density in the neocortex of $A P P_{\text {swe }} / P S 1_{\mathrm{dE} 9}$ mice compared to WT animals [Fig. 1a; genotype effect: $F_{(1,200)}=7.8, p=0.006$, three-way ANOVA]. The reduction was observed in the frontal and parietal, rather than the occipital and temporal cortices of TG animals. In the frontal cortex, there were genotype $\left[F_{(1,50)}=8.0, p=0.007\right]$ and genotype $\times$ age 

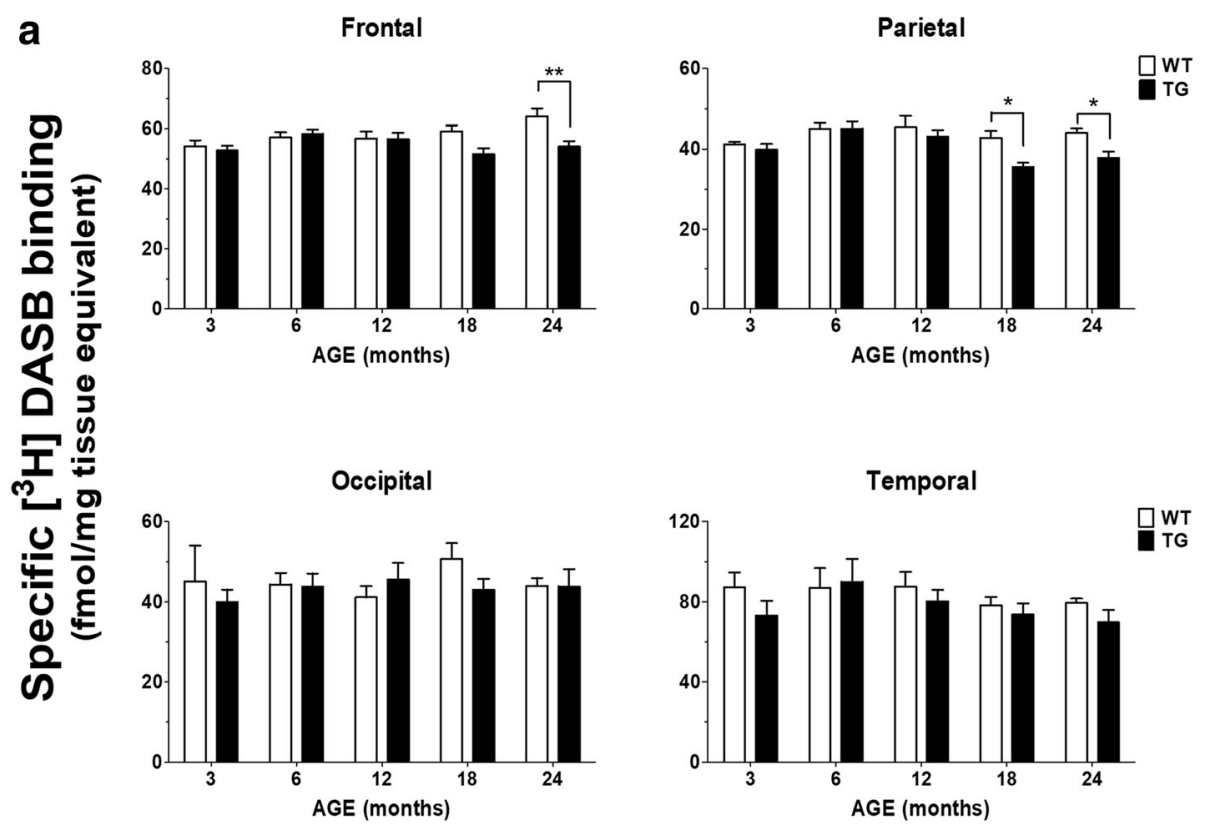

b
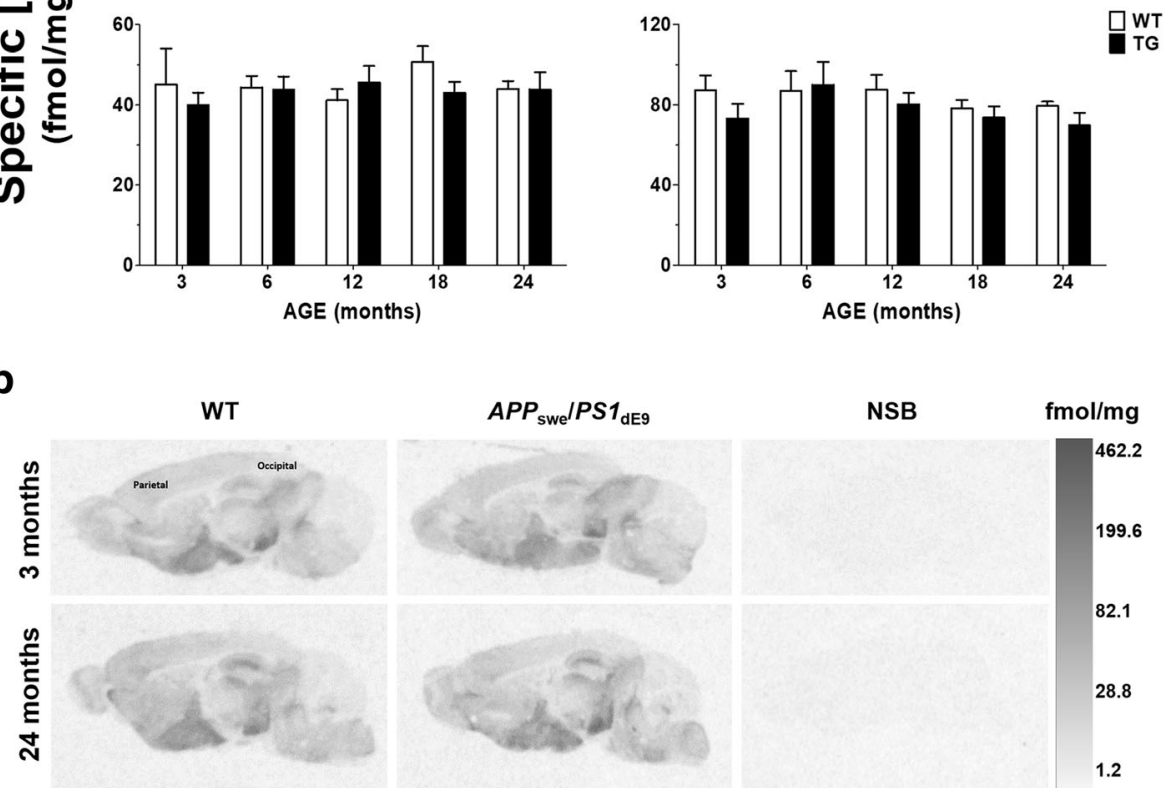

Fig. 1 Autoradiography of SERT binding sites. a Quantification of [ $\left.{ }^{3} \mathrm{H}\right] \mathrm{DASB}$ binding in the neocortex of aging wild-type (WT) and $A P P_{\mathrm{swe}} / P S 1_{\mathrm{dEg}}$ transgenic $(\mathrm{TG})$ mice. Values represent the mean specific binding of $\left[{ }^{3} \mathrm{H}\right] \mathrm{DASB} \pm \mathrm{SEM}$ in six animals/group. For each animal, binding was determined in six consecutive sections containing the frontal, parietal and occipital cortex, and two consecutive sections containing the temporal cortex. Reduced SERT density was observed in the frontal and parietal cortices of APP swe $_{P} / P S 1_{\mathrm{dEg}} \mathrm{Vs}$. WT control animals, at 24 and 18 months of age respectively. ${ }^{*} p<0.05,{ }^{* *} p<0.01$ vs. age-matched WT, two-way ANOVA followed by Bonferroni posttests. $\mathbf{b}$ Representative autoradiograms of SERT binding sites. Images are shown at lateral $0.96-1.20 \mathrm{~mm}$, containing the parietal and occipital cortex. The bar represents a scale of black and white image density, calibrated in fmol/mg of tissue equivalent. Levels of specific binding were calculated following subtraction of non-specific binding (NSB) from total binding images. NSB was determined with $10 \mu \mathrm{M}$ paroxetine $\mathrm{HCl}$ hemihydrate and was indistinguishable

from background

interaction effects on the binding levels of $\left[{ }^{3} \mathrm{H}\right] \mathrm{DASB}$ $\left[F_{(4,50)}=3.0, p=0.027\right.$, two-way ANOVA $]$, which were decreased in 24-month-old $A P P_{\mathrm{swe}} / P S 1_{\mathrm{dE} 9}$ vs. WT control mice $(p<0.01$; Bonferroni posttests). In the parietal cortex, age- $\left[F_{(4,50)}=4.9, p=0.002\right]$ and genotype-induced $\left[F_{(1,50)}=11.1, p=0.002\right]$ decreases in SERT density were observed in 18- and 24-month-old TG vs. WT animals $(p<0.05$; Bonferroni posttests). There were no effects of genotype $\left[F_{(1,50)}=0.5, p=0.50\right]$ and age $\left[F_{(4 \text {, }}\right.$ 50) $=0.3, p=0.87]$ on the density of SERT in the occipital cortex and the temporal cortex [genotype effect: $F_{(1,50)}$ $=2.1, \quad p=0.16 ; \quad$ age effect: $\left.\left.F_{(4,} 50\right)=1.3, \quad p=0.30\right]$.
Representative autoradiograms of $\left[{ }^{3} \mathrm{H}\right]$ DASB-binding sites are shown in Fig. 1b.

No change in Sert expression in aging $A P P_{\text {swe }} / P S 1_{d E g}$ and WT mice

Two-way ANOVA showed no effects of age $\left[F_{(4,48)}=1.5\right.$, $p=0.21]$ and genotype $\left[F_{(1,48)}=2.8, p=0.09\right]$, and no genotype $\times$ age interaction effects $\left[F_{(4,48)}=0.3, p=0.88\right]$ on the mRNA expression levels of Sert (Fig. 2). PCR products of $5 \times$ diluted Sert cDNA were determined after 24 cycles. A single peak at $81{ }^{\circ} \mathrm{C}$ was obtained by melt-curve analysis, and no signal detected in the genomic DNA and 


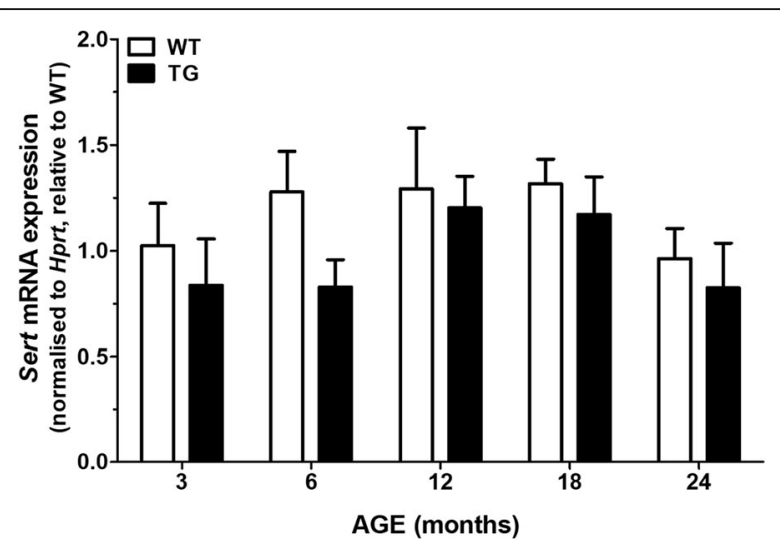

Fig. 2 Sert mRNA expression in aging wild-type and $A P P_{\text {swe }} / P S 1_{\mathrm{dE} 9}$ mice. The brainstem from the left hemisphere of wild-type (WT) and $A P P_{\text {swe }} / P S 1_{\mathrm{dEg}}$ transgenic (TG) mice was isolated for evaluating Sert mRNA expression by RT-qPCR. No differences in the regulation of Sert expression were detected between WT and TG animals. Hprt was used as a reference gene. Values represent fold-changes from the mean Sert/Hprt ratio of 3-month-old WT mice \pm SEM

buffer controls. The efficiency of amplification was $94.0 \pm$ $3.1 \%$ for Sert and $99.2 \pm 0.1 \%$ for Hprt.

The rate of $\left[{ }^{3} \mathrm{H}\right] 5-\mathrm{HT}$ uptake is decreased in the neocortex of aged $\mathrm{APP}_{\text {swe }} / \mathrm{PS} 1_{\mathrm{dEg}}$ mice, and following incubation with soluble $A \beta_{40}$

The $\left[{ }^{3} \mathrm{H}\right] 5$-HT transport assay was used to assess SERT activity in membrane suspensions from aging WT and $A P P_{\text {swe }} / P S 1_{\mathrm{dE} 9}$ TG mice (Table 1 ). Kinetic analysis revealed significant genotype $\times$ age interaction effects on the $V_{\max }$ of $\left[{ }^{3} \mathrm{H}\right] 5-\mathrm{HT}$ uptake $\left[F_{(3,21)}=5.1, p=0.008\right]$, which was reduced in 20-month-old TG vs. WT animals $\left(p<0.05\right.$; Bonferroni posttests). No main effects of age $\left[F_{(3}\right.$, 21) $=0.6, p=0.65]$ and genotype $\left[F_{(1,21)}=0.3, p=0.61\right]$, and no age $\times$ genotype interaction effects were observed on the SERT $K_{m}\left[F_{(3,21)}=0.1, p=0.94\right]$. The ratio of $V_{\max } / K_{m}$ was calculated as an index of SERT's efficiency for the uptake of $\left[{ }^{3} \mathrm{H}\right] 5-\mathrm{HT}$. There were no age $\left[F_{(3,21)}=2.1, p=0.13\right]$, genotype $\left[F_{(1,21)}=0.4, p=0.52\right]$ and age $\times$ genotype interaction effects on the $V_{\max } / K_{\mathrm{m}}$ ratio by two-way ANOVA $\left[F_{(3,21)}=1.3, p=0.29\right]$. By one-way ANOVA, the $V_{\max } / K_{\mathrm{m}}$ ratio decreased in an age-dependent manner in $A P P_{\text {swe }} /$ $P S 1_{\mathrm{dE9}}$ mice $\left[F_{(3,10)}=3.9, p=0.045\right]$. However, the reduction was small, and individual Bonferroni comparisons did not reveal significant differences in SERT's efficiency between groups of aging TG mice $(p>0.05)$.

The effects of soluble $A \beta_{40}$ and $A \beta_{42}(100 \mathrm{nM})$ on the baseline transport of $\left[{ }^{3} \mathrm{H}\right] 5-\mathrm{HT}$ were examined in membranes isolated from the forebrain of 3-month-old WT mice (Fig. 3a). A $\beta_{40}$ reduced the baseline $V_{\max }$ of $\left[{ }^{3} \mathrm{H}\right] 5-\mathrm{HT}$ uptake from $1832 \pm 79 \mathrm{fmol} / \mathrm{min} / \mathrm{mg}$ to 1490 $\pm 91 \mathrm{fmol} / \mathrm{min} / \mathrm{mg}\left[t_{(7)}=2.6, p=0.034\right]$, without altering the SERT $K_{\mathrm{m}}\left[t_{(7)}=1.0, p=0.35\right]$. Soluble $\mathrm{A} \beta_{42}$ had no effect on the baseline $V_{\max }\left[t_{(7)}=0.1, p=0.89\right]$ and $K_{\mathrm{m}}$ of $\left[{ }^{3} \mathrm{H}\right] 5$-HT transport $\left[t_{(7)}=0.3, p=0.78\right] .\left[{ }^{3} \mathrm{H}\right] \mathrm{DASB}$ was not displaced by increasing concentrations of soluble $\mathrm{A} \beta_{40}$ or $\mathrm{A} \beta_{42}$ (Fig. 3b).

\section{Increased $\left[{ }^{3} \mathrm{H}\right] \mathrm{PK} 11195$ binding in the neocortex of aging} $\mathrm{APP}_{\text {swe }} / \mathrm{PS} 1_{\mathrm{dEg}}$ and WT control mice

Brain sections adjacent to those labeled for SERT were used to measure TSPO binding levels by $\left[{ }^{3} \mathrm{H}\right] \mathrm{PK} 11195$ autoradiography (Fig. 4a). Representative autoradiograms are presented in Fig. 4b.

There were increased TSPO-binding levels in the neocortex of $A P P_{\text {swe }} / P S 1_{\mathrm{dE} 9}$ TG vs. WT control animals [genotype effect: $F_{(1,200)}=21.8, p=0.000$; three-way ANOVA]. Age-dependent increases in cortical TSPO levels were observed in both TG and WT mice [age effect: $\left.F_{(4,200)}=74.5, p=0.000\right]$, but were more prominent in TG animals [genotype $\times$ age interaction effect: $F_{(4 \text {, }}$ 200) $=7.97, p=0.000]$. In the frontal cortex, $\left[{ }^{3} \mathrm{H}\right] \mathrm{PK} 11195$ binding was increased in $12-(p<0.05)$ and 24-monthold TG vs. WT animals $(p<0.01)$, as well as in $12-24$ compared to 3-6-month-old TG mice $(p<0.01-0.001$; Bonferroni posttests). Two-way ANOVA confirmed significant age $\left[F_{(4,50)}=19.4, p=0.000\right]$, genotype $\left[F_{(1}\right.$, 50) $=11.6, p=0.001]$, and age $\times$ genotype interaction

Table 1 Saturation analysis of $\left[{ }^{3} \mathrm{H}\right] 5-\mathrm{HT}$ uptake in brain membrane preparations from wild-type and $A P P_{\text {swe }} / P S 1_{\mathrm{dE} 9}$ mice

\begin{tabular}{|c|c|c|c|c|c|c|}
\hline & \multicolumn{2}{|l|}{$V_{\max }$} & \multicolumn{2}{|l|}{$K_{\mathrm{m}}$} & \multicolumn{2}{|l|}{$V_{\max } / K_{\mathrm{m}}$} \\
\hline & \multicolumn{2}{|c|}{ (fmol/min/mg total protein) } & \multicolumn{2}{|l|}{$(\mu \mathrm{M})$} & \multicolumn{2}{|c|}{$(\mu \mathrm{L} / \mathrm{min} / \mathrm{mg}$ total protein) } \\
\hline & WT & TG & WT & $\mathrm{TG}$ & $\overline{W T}$ & TG \\
\hline 3 months & $958 \pm 55$ & $1166 \pm 88$ & $0.076 \pm 0.022$ & $0.069 \pm 0.029$ & $12.6 \pm 2.5$ & $16.8 \pm 3.1$ \\
\hline 6 months & $1060 \pm 76$ & $1134 \pm 72$ & $0.078 \pm 0.028$ & $0.086 \pm 0.027$ & $13.6 \pm 2.7$ & $13.1 \pm 2.6$ \\
\hline 12 months & $1112 \pm 89$ & $1106 \pm 83$ & $0.094 \pm 0.036$ & $0.131 \pm 0.043$ & $11.8 \pm 2.5$ & $8.4 \pm 2.0$ \\
\hline 20 months & $1182 \pm 93$ & $792 \pm 74^{*}$ & $0.099 \pm 0.037$ & $0.114 \pm 0.048$ & $11.9 \pm 2.5$ & $7.0 \pm 1.6$ \\
\hline
\end{tabular}

Values are reported as the mean \pm SEM of 3-4 independent experiments, conducted on freshly prepared membranes from the neocortex of aging wild-type (WT) and $A P P_{\text {swe }} / P S 1_{\mathrm{dEg}}$ littermate transgenic (TG) mice. The apparent maximal velocity rate $\left(V_{\text {max }}\right)$ for the uptake of $\left.{ }^{3} \mathrm{H}\right] 5-\mathrm{HT}$ was reduced in 20 -month-old TG vs. WT animals, without a change in the apparent Michaelis constant $\left(K_{\mathrm{m}}\right)$. By one-way ANOVA, there was a modest, age-dependent reduction in the efficiency $\left(V_{\mathrm{max}} / K_{\mathrm{m}}\right)$ of SERT in $A P P_{\text {swe }} / P S 1_{\mathrm{dEg}}$ mice, which did not reach between-group significance by Bonferroni post hoc tests. ${ }^{*} p<0.05$ vs. age-matched WT, two-way ANOVA followed by Bonferroni posttests 

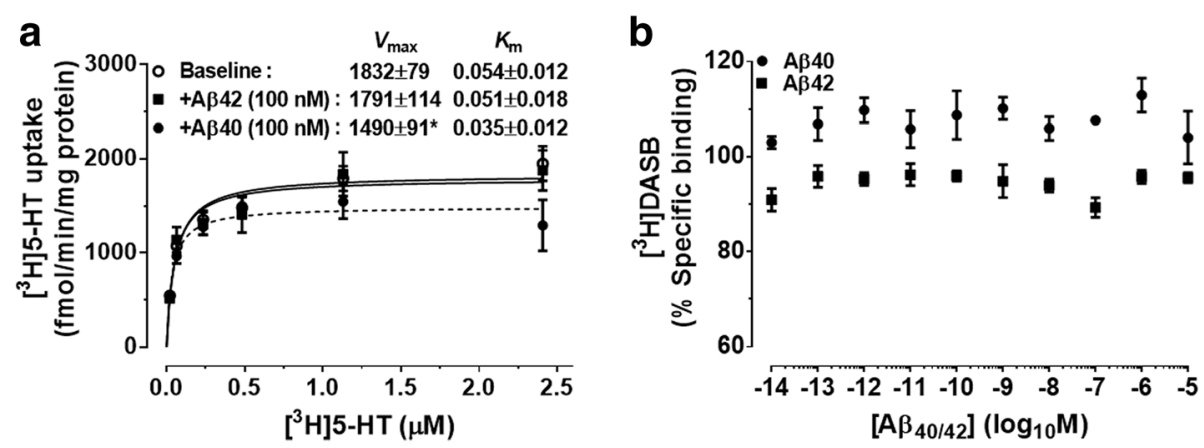

Fig. 3 Inhibition of SERT activity by soluble $A \beta_{40}$ a Forebrain membrane preparations from 3-month-old wild-type mice were incubated for 5 min with increasing concentrations of $\left.{ }^{3} \mathrm{H}\right] 5-\mathrm{HT}(20 \mathrm{nM}-2.5 \mu \mathrm{M})$, in the presence or absence of human amyloid- $\beta(\mathrm{A} \beta)_{40 / 42}$. Peptide concentrations of $100 \mathrm{nM}$ were used, based on the levels of soluble $A \beta_{40 / 42}$ measured in the neocortex of 20-month-old APP swe $_{\text {PST }}$ dE9 mice by Meso Scale Discovery. $A \beta_{40}$ reduced the apparent maximal velocity rate $\left(V_{\max }\right)$ of $\left[{ }^{3} \mathrm{H}\right] 5-\mathrm{HT}$ uptake, without changing the apparent Michaelis constant $\left(K_{\mathrm{m}}\right)$. $\mathrm{A} \beta_{42}$ had no effect on the uptake kinetics of $\left[{ }^{3} \mathrm{H}\right] 5-\mathrm{HT}$. Results represent the mean \pm SEM values of three independent experiments, each conducted in triplicate. $\mathbf{b}$ Forebrain membrane preparations were incubated for $2 \mathrm{~h}$ with $2 \mathrm{nM}\left[{ }^{3} \mathrm{H}\right] \mathrm{DASB}$, in the presence or absence of increasing concentrations of $A \beta_{40 / 42}(0.01 \mathrm{pM}-10 \mu \mathrm{M})$. The inhibitory effects of $A \beta_{40}$ were not due to competition at the $\left[^{3} \mathrm{H}\right] \mathrm{DASB}$-binding site

effects on $\left[{ }^{3} \mathrm{H}\right] \mathrm{PK} 11195$ binding in the frontal cortex $\left[F_{(4,50)}=3.7, p=0.010\right]$. In the parietal cortex, increased binding of $\left[{ }^{3} \mathrm{H}\right] \mathrm{PK} 11195$ was observed in $18-(p<0.01)$ and 24-month-old $A P P_{\text {swe }} / P S 1_{\mathrm{dE} 9}$ TG mice, compared to age-matched WT animals $(p<0.05$; Bonferroni posttests). Age-dependent increases were observed in 18-24 vs. 3-month-old WT mice $(p<0.05-0.01)$, as well in $12-$ 24 vs. $3-6$-month-old TG animals $(p<0.001$; Bonferroni posttests). Two-way ANOVA in the parietal cortex showed significant main effects of age $\left[F_{(4,50)}=27.2, p=0.000\right]$ and genotype $\left[F_{(1,50)}=13.3, p=0.001\right]$, as well as significant age $\times$ genotype interaction effects $\left[F_{(4,50)}=3.3, p=0.019\right]$. In the temporal cortex, $\left[{ }^{3} \mathrm{H}\right] \mathrm{PK} 11195$-binding levels increased in 24-month-old animals compared to all other age groups examined [age effect: $F_{(4,50)}=25.3, p=0.000 ; p<0.01-$ 0.001 ; Bonferroni posttests], irrespective of genotype $\left[F_{(1}\right.$, 50) $=0.6, p=0.45]$. In the occipital cortex, there were genotype-induced effects on the levels of TSPO $\left[F_{(1,50)}=\right.$ 7.9, $p=0.007$, which were increased in 12-month-old TG vs. WT mice $(p<0.05$; Bonferroni posttests). Age -dependent increases in TSPO-binding levels $\left[F_{(4,50)}=15.3\right.$, $p=0.000$ ] were observed in 24- vs. 3-month-old WT animals $(p<0.05)$, and $12-24$ vs. $3-6$-month-old TG mice ( $p<0.01-0.001$; Bonferroni posttests).

Age-dependent changes in the binding levels of $\left[{ }^{3} \mathrm{H}\right] \mathrm{PK} 11195$ were inversely correlated with $\left[{ }^{3} \mathrm{H}\right] \mathrm{DASB}--$ binding levels in the parietal, but not the frontal, occipital, and temporal cortices of $A P P_{\mathrm{swe}} / P S 1_{\mathrm{dE} 9}$ TG mice (Fig. 5).

Increased levels of IL-1 $\beta$, IL-6, and TNF in the neocortex of aging $A P P_{\text {swe }} / P S 1_{d E g}$ and WT control mice

The concentration of IL- $1 \beta$, IL- 6 , and TNF was measured in the S1 supernatant fraction from the neocortex of 3-, 6-, 12-, and 20-month-old WT and TG animals (Table 2).

Levels of IL-6 were increased in 20 vs. 3-month-old animals $(p<0.05$; Bonferroni posttests), irrespective of genotype $\left[F_{(1,31)}=0.0, p=0.92\right]$. Two-way ANOVA revealed significant main effects of age on the concentration of IL-6 $\left[F_{(3,31)}=3.8, p=0.02\right]$, with no age $\times$ genotype interaction effects $\left[F_{(3,31)}=1.3, p=0.30\right]$. The concentration of TNF increased in the cortex of 6- $(p<0.05), 12-(p<0.05)$, and 20-month-old animals $(p<0.0001$; Bonferroni posttests) compared to 3 -month-old mice [age effect: $F_{(3,31)}=11.7, p=0.000$ ]. There were no main effects of genotype $\left[F_{(1,31)}=3.1\right.$, $p=0.09]$, and no genotype $\times$ age interaction effects on TNF levels $\left[F_{(3,31)}=2.4, p=0.09\right]$. The concentration of IL-1 $\beta$ was higher in $A P P_{\mathrm{swe}} / P S 1_{\mathrm{dEg}}$ TG compared to WT control mice [genotype effect: $F_{(1,31)}=9.4, p=0.004$ ], increasing by age $\left[F_{(3,31)}=3.5, p=0.000\right]$, primarily in TG animals [age $\times$ genotype interaction effect: $F_{(3,31)}=$ 9.4, $p=0.026]$. Higher concentrations of IL-1 $\beta$ were measured in 12 -month-old TG vs. WT mice $(p<0.05)$, as well as in 20-month-old compared to $3-(p<0.001)$ and 6-month-old TG animals $(p<0.05$; Bonferroni posttests).

Age-related changes in the ratio of soluble $A \beta_{40} / A \beta_{42}$ in the neocortex of $\mathrm{APP}_{\text {swe }} / \mathrm{PS}_{\mathrm{dEg}}$ mice

Levels of $A \beta_{40}$ and $A \beta_{42}$ were measured in the S1 supernatant fraction from 3-, 6-, 12-, and 20-month-old WT and TG animals (Table 3 ). There were significant main effects of age $\left[F_{(3,51)}=13.5, p=0.000\right]$ and genotype $\left[F_{(1}\right.$, $51)=30.4, p=0.000]$, as well as significant age $\times$ genotype interaction effects on the levels of soluble $\mathrm{A} \beta_{40}\left[F_{(3,51)}\right.$ $=13.6, p=0.000]$, which were increased in the cortex of 

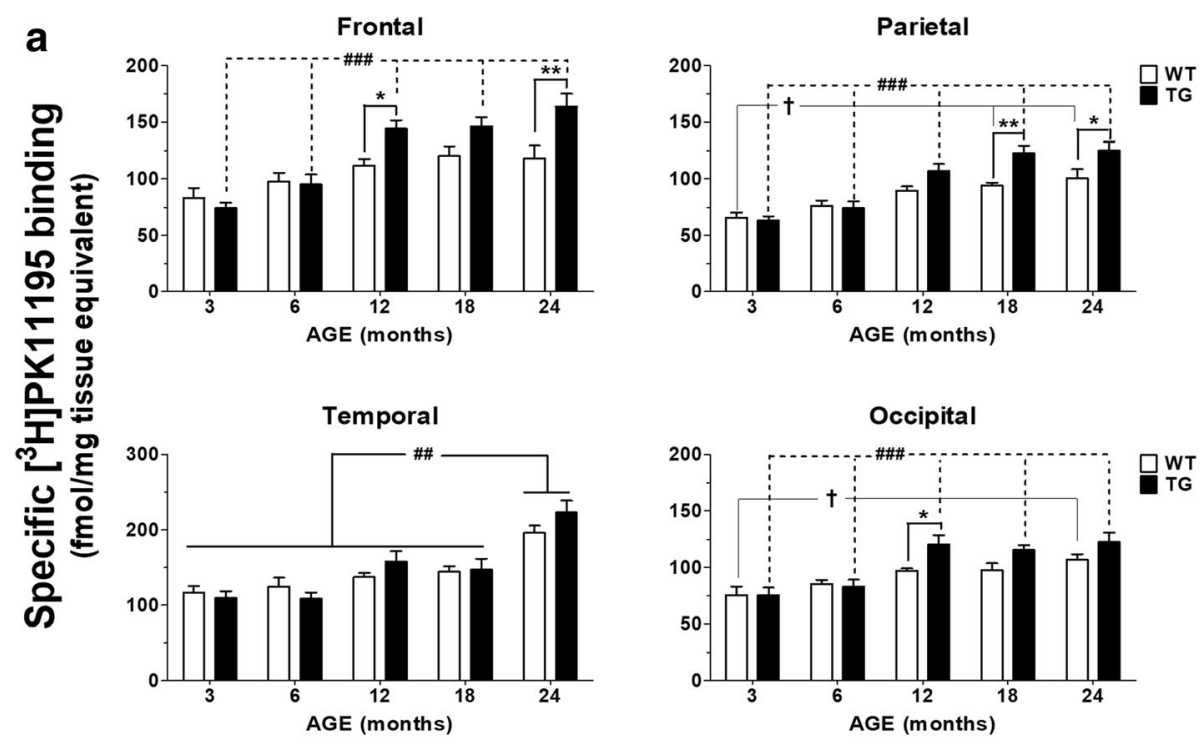

b

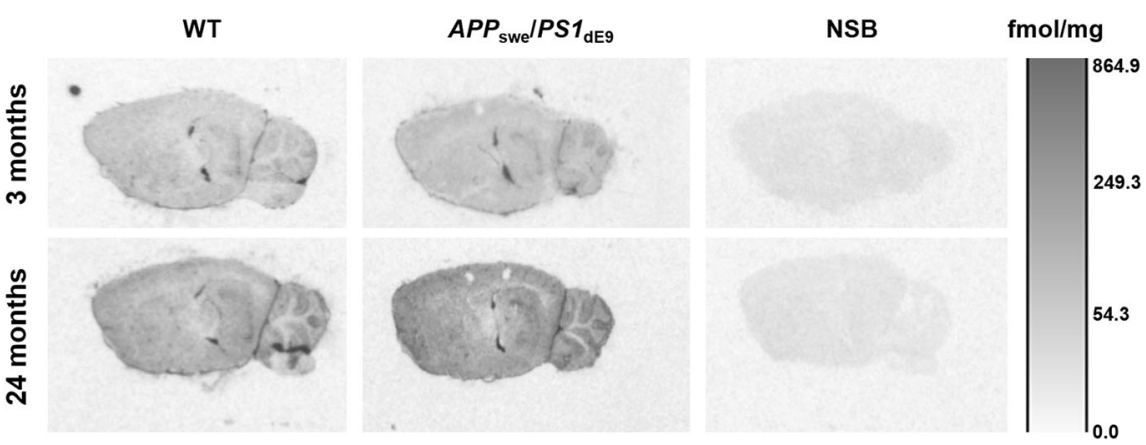

Fig. 4 Autoradiography of TSPO-binding sites. a Quantification of $\left[{ }^{3} \mathrm{H}\right] \mathrm{PK} 11195$ binding in the neocortex of aging wild-type (WT) and APP $\mathrm{swe}$ $P S 1_{\mathrm{dEg}}$ transgenic (TG) mice. Values represent the mean-specific binding of $\left.{ }^{3} \mathrm{H}\right] \mathrm{PK} 11195 \pm$ SEM in six animals/group. Levels of the translocator protein (TSPO) were increased by age in both TG and WT animals, but the increase was more prominent in APP swe $_{\text {PS }} 1_{\mathrm{dEg}}$ mice. Significant differences between age-matched TG and WT animals are denoted by stars $\left({ }^{*}\right)$. Age-dependent differences between groups of TG and WT animals in the frontal, parietal, and occipital cortices are denoted by hashes $\left({ }^{*}\right)$ and daggers $\left({ }^{\dagger}\right)$, respectively. Two-way ANOVA analysis is shown, followed by Bonferroni post hoc tests. b Representative autoradiograms of $\left.{ }^{3} \mathrm{H}\right]$ PK1 1195-binding sites, presented at lateral $2.64-2.88 \mathrm{~mm}$. The bar represents a scale of black and white image density, calibrated in fmol/mg of tissue equivalent. Levels of specific binding were calculated following subtraction of non-specific binding (NSB) from total binding images. NSB was determined with $10 \mu \mathrm{M}$ unlabeled PK11195 and amounted to $\sim 20 \%$ of total radioligand binding

20-month-old TG animals, compared to all other groups examined ( $p<0.001$; Bonferroni posttests). Soluble $\mathrm{A} \beta_{42}$ levels were increased in 20-month-old compared to 3 $(p<0.001)$ and 6 -month-old TG mice $(p<0.001)$ and compared to groups of WT animals $(p<0.001$; Bonferroni posttests). Two-way ANOVA confirmed significant main effects of age $\left[F_{(3,51)}=6.6, p=0.001\right]$ and genotype $\left[F_{(1,51)}=25.2, p=0.000\right]$, as well as significant age $\times$ genotype interaction effects on $\mathrm{A} \beta_{42}$ levels $\left[F_{(3,51)}=6.6\right.$, $p=0.001]$. In TG mice, the ratio of $\mathrm{A} \beta_{40}: \mathrm{A} \beta_{42}$ was decreased in $6-(p<0.05)$ and $12-(p<0.01)$ compared to 3 -month-old animals, but increased in 20-month-old, compared to 6- $(p<0.01)$ and 12 -month-old TG mice $\left(p<0.001\right.$; Bonferroni posttests; one-way ANOVA: $F_{(3}$, 27) $=10.9, p=0.024]$.

\section{Discussion}

In the present work, age-dependent changes in the density and function of the SERT were assessed in parallel with markers of neuroinflammation in the neocortex of $A P P_{\mathrm{swe}} / P S 1_{\mathrm{dE} 9}$ mice. Increased levels of the neuroinflammatory markers TPSO and IL-1 $\beta$ preceded reductions in the density and activity of the SERT, which were observed in aged, 18-24-month-old TG animals. There was no indication of direct, cytokine-induced alterations in the binding levels of SERT, at any of the time-points examined. However, there was an $A \beta_{40}$-induced reduction in the rate of $\left[{ }^{3} \mathrm{H}\right] 5-\mathrm{HT}$ uptake, indicating that SERT activity, and the effects of SERT antagonism, may depend on amyloid status. 


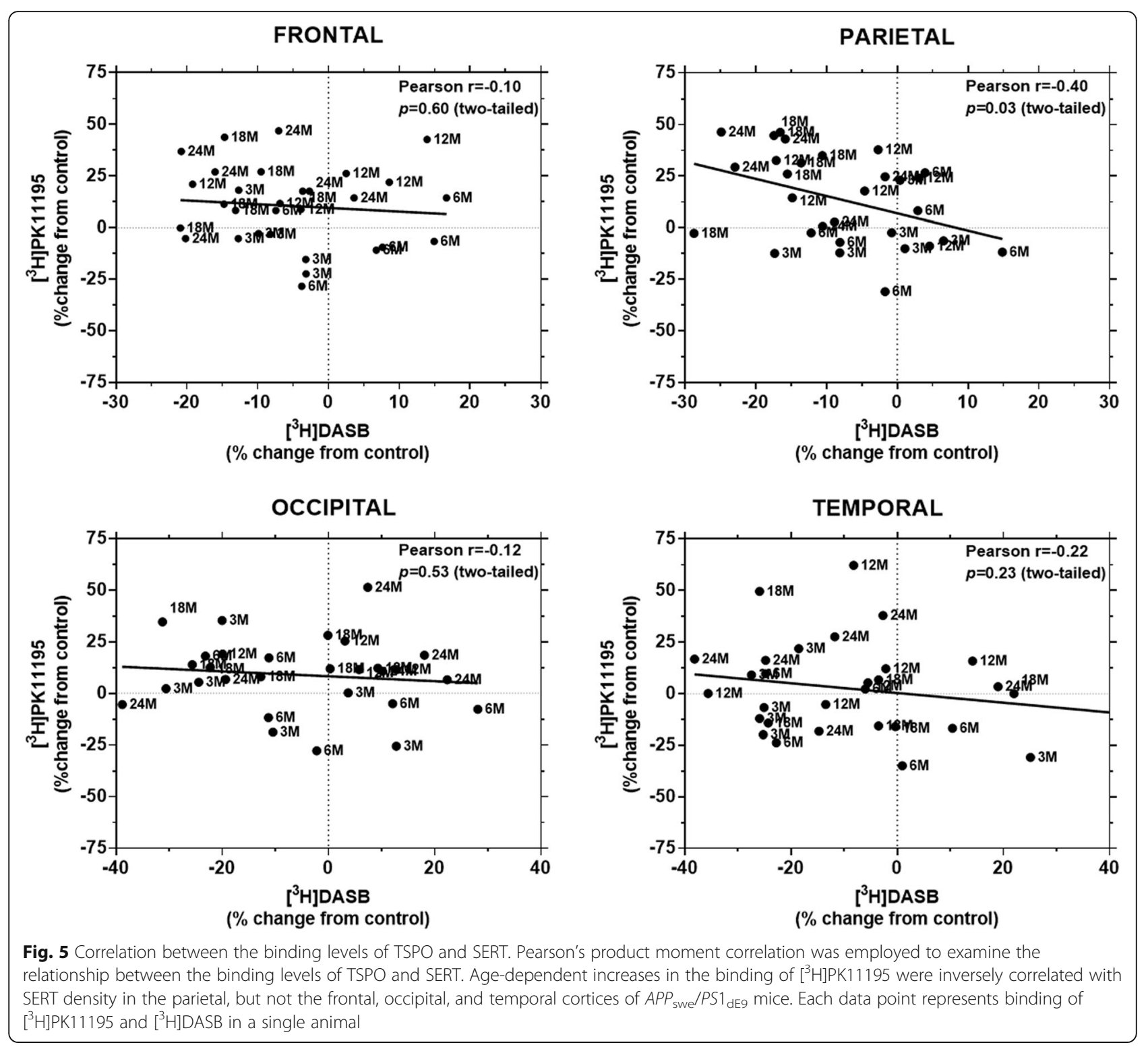

Table 2 Increased levels of pro-inflammatory cytokines in the neocortex of wild-type and APP $P_{\text {swe }} / P S 1_{\mathrm{dEg}}$ mice

\begin{tabular}{|c|c|c|c|c|c|c|}
\hline & \multicolumn{2}{|l|}{$I L-1 \beta$} & \multicolumn{2}{|l|}{ IL-6 } & \multicolumn{2}{|l|}{ TNF } \\
\hline & \multicolumn{2}{|c|}{ (pg/mg total protein) } & \multicolumn{2}{|c|}{ (pg/mg total protein) } & \multicolumn{2}{|c|}{ (pg/mg total protein) } \\
\hline & $\overline{W T}$ & TG & $\overline{W T}$ & $\mathrm{TG}$ & $\overline{W T}$ & TG \\
\hline 3 months & $0.17 \pm 0.01$ & $0.14 \pm 0.02^{\# \#}$ & $1.59 \pm 0.71$ & $2.08 \pm 0.49$ & $0.08 \pm 0.03$ & $0.09 \pm 0.02$ \\
\hline 6 months & $0.18 \pm 0.03$ & $0.23 \pm 0.02^{\#}$ & $2.80 \pm 0.58$ & $3.49 \pm 0.33$ & $0.11 \pm 0.03$ & $0.19 \pm 0.03$ \\
\hline 12 months & $0.18 \pm 0.02$ & $0.33 \pm 0.05^{* *}$ & $2.92 \pm 0.45$ & $3.20 \pm 0.50$ & $0.14 \pm 0.02$ & $0.18 \pm 0.01$ \\
\hline 20 months & $0.27 \pm 0.03$ & $0.38 \pm 0.04$ & $4.39 \pm 0.80$ & $3.10 \pm 0.54$ & $0.23 \pm 0.02$ & $0.20 \pm 0.02$ \\
\hline
\end{tabular}

The concentration of IL-1 $\beta, \mathrm{IL}-6$, and TNF was measured in the S1 supernatant fraction from neocortical homogenates of aging wild-type (WT) and APP swe $_{\text {PS }} 1_{\mathrm{dEg}}$ transgenic (TG) mice, by using Meso Scale Discovery. Genotype-induced effects on cytokine levels were solely observed for IL-1 $\beta$, which was increased over agematched control values at the 12-month time-point. The concentration of all pro-inflammatory cytokines increased with age, in both TG and WT animals. Values of IL-1 $\beta$, IL- 6 , and TNF were normalized to total protein content and reported as the mean \pm SEM of 3-4 independent experiments. ${ }^{* *} p<0.01$ vs. 12 -month-old WT; ${ }^{\#} p<0.05, \# p<0.01$ vs. 20-month-old TG, two-way ANOVA followed by Bonferroni posttests 
Table 3 Increased levels of soluble $A \beta_{40 / 42}$ in the neocortex of $A P P_{\text {swe }} / P S 1_{\text {dEg }}$ mice

\begin{tabular}{|c|c|c|c|c|c|}
\hline & \multicolumn{2}{|l|}{$A \beta_{40}$} & \multicolumn{2}{|l|}{$A \beta_{42}$} & \multirow{3}{*}{$\begin{array}{l}A \beta_{40:} A \beta_{42} \\
T G\end{array}$} \\
\hline & \multicolumn{2}{|c|}{ (pg/mg total protein) } & \multicolumn{2}{|c|}{ (pg/mg total protein) } & \\
\hline & $\overline{W T}$ & TG & $\overline{W T}$ & TG & \\
\hline 3 months & $3.7 \pm 0.9$ & $44.3 \pm 3.5$ & $1.6 \pm 0.4$ & $14.8 \pm 2.8$ & $3.2 \pm 0.3$ \\
\hline 6 months & $2.6 \pm 0.6$ & $90.0 \pm 12.5$ & $0.8 \pm 0.1$ & $55.4 \pm 13.2$ & $1.9 \pm 0.2^{* *}, \# \#$ \\
\hline 12 months & $4.2 \pm 1.5$ & $306.2 \pm 38.5$ & $1.7 \pm 0.6$ & $197.0 \pm 26.3$ & $1.6 \pm 0.1^{*}$, \#\#\# \\
\hline 20 months & $2.8 \pm 1.2$ & $1031.2 \pm 184.4^{* * *}$ & $1.1 \pm 0.4$ & $340.6 \pm 81.6^{* * *}$ & $3.4 \pm 0.4$ \\
\hline
\end{tabular}

Soluble amyloid- $\beta(A \beta)$ was measured in the $S 1$ supernatant fraction from neocortical homogenates of aging wild-type (WT) and APP swe/PS1 $1_{\text {dEg }}$ transgenic (TG) mice, by using Meso Scale Discovery. $A \beta_{40 / 42}$ values were normalized to total protein content and reported as the mean \pm SEM of 3-4 independent experiments. Age-dependent increases in the concentration of soluble $A \beta_{40 / 42}$ were observed exclusively in $A P P_{\text {swe }} / P S 1_{\text {deg }}$ mice. The proportion of $A \beta_{40}$ in the $A \beta_{40}: A \beta_{42}$ ratio increased in 20- vs. 6- and 12-month-old TG mice. ${ }^{*} p<0.05,{ }^{* *} p<0.01$, and ${ }^{* * *} p<0.001$ vs. 3-month-old TG mice, two-way ANOVA followed by Bonferroni posttests: $\# p<0.01$ and ${ }^{\# \# \#} p<0.001$ vs. 20-month-old TG mice, one-way ANOVA followed by Bonferroni posttests

SERT density is considered to be a representative marker of the integrity of the serotonergic afferents, given that the transporter is primarily located on serotonergic nerve terminals and axons in the adult brain [28]. In humans, postmortem SERT autoradiography [29, 30], as well as neuroimaging studies with the SERT-selective tracer $\left[{ }^{11} \mathrm{C}\right]$ DASB $[31,32]$, has reported reduced SERT availability in the neocortex of AD patients, compared to non-demented subjects. In keeping with this literature, the binding of $\left[{ }^{3} \mathrm{H}\right] \mathrm{DASB}$ decreased in the frontal and parietal cortex of $18-24-$ month-old $A P P_{\mathrm{swe}} / P S 1_{\mathrm{dEg}}$ mice, a reduction that is likely associated with degenerative changes in the serotonergic terminals of aged TG animals. Supporting this suggestion, Sert mRNA levels were not different between TG and WT mice, indicating that the decreased binding of $\left[{ }^{3} \mathrm{H}\right] \mathrm{DASB}$ is not due to decreased Sert expression, at least when the entire raphe nuclei are assayed by RT-qPCR [24]. These findings are consistent with reports that the density of serotonergic axons is reduced by $\sim 50 \%$ in the neocortex of 18 month-old $A P P_{\text {swe }} / P S 1_{\mathrm{dE}}$ mice, as evidenced by stereological analysis of 5-HT immunostained fibers [14]. The decrease in $\left[{ }^{3} \mathrm{H}\right] \mathrm{DASB}$ binding further ties in with the reduction in the $V_{\max }$ of $\left[{ }^{3} \mathrm{H}\right] 5-\mathrm{HT}$ uptake in 20-month-old TG vs. WT animals, since the velocity of substrate uptake depends on the concentration of transporter protein according to Michaelis-Menten kinetics. In terms of the therapeutic efficacy of SSRIs in AD, these results suggest that the effects of SERT antagonism may decline at the advanced stages of amyloidosis, in accordance with the reduction in the availability of SERT.

In addition to potential disruptions in cortical serotonergic innervation, the addition of $A \beta_{40}$ in membrane preparations from WT animals reduced the $V_{\max }$ of $\left[{ }^{3} \mathrm{H}\right] 5-\mathrm{HT}$ uptake from its control value by $\sim 20 \%$. The magnitude of decrease is within the range reported by studies assaying SERT activity in biopsy specimens from the neocortex of $\mathrm{AD}$ patients [33,34]. The effect of $\mathrm{A} \beta_{40}$ is likely due to a non-competitive mode of SERT inhibition, since we observed reductions in the $V_{\max }$ rather than the $K_{\mathrm{m}}$ of $\left[{ }^{3} \mathrm{H}\right] 5-\mathrm{HT}$, and lack of displacement at the $\left[{ }^{3} \mathrm{H}\right]$ DASB-binding site. Moreover, the reduction in SERT activity was induced by $A \beta_{40}$, and not by the more lipophilic $A \beta_{42}$ species, implying inhibition of active $\left[{ }^{3} \mathrm{H}\right] 5$-HT transport, rather than a reduction in the permeation of $\left[{ }^{3} \mathrm{H}\right] 5-\mathrm{HT}$. These data point towards a functional interaction between amyloidosis and the SERT, which may dysregulate serotonergic transmission in response to accumulating $A \beta_{40}$. In fact, it is important to note that the reduction in the $V_{\max }$ of $\left[{ }^{3} \mathrm{H}\right] 5-\mathrm{HT}$ uptake in 20-month-old transgenic vs. wild-type animals coincided with a shift in the ratio of $A \beta_{40 / 42}$ towards $A \beta_{40}$, an observation on the regulation of soluble $A \beta$ that we have previously reported in aging $A P P_{\mathrm{swe}} / P S 1_{\mathrm{dE}}$ mice [18].

Acute SSRI treatment has been shown to immediately reduce the levels of $A \beta_{40 / 42}$ in the brain interstitial fluid of $A P P_{\mathrm{swe}} / P S 1_{\mathrm{dE} 9}$ mice [35], as well as in the cerebrospinal fluid of healthy human volunteers [36], supporting a direct association between SERT function and amyloidosis. However, the A $\beta$-lowering effects of SSRIs have not been reported consistently in humans [37], nor in $A P P_{\mathrm{swe}} / P S 1_{\mathrm{dE}}$ mice [38]. Studies on the kinetics of $\left[{ }^{3} \mathrm{H}\right] 5-\mathrm{HT}$ uptake in platelets from AD patients have also been inconsistent, reporting decreased $V_{\max }$ and $K_{\mathrm{m}}$ [39], decreased $V_{\max }$ and unaltered $K_{\mathrm{m}}$ [40], and cognitive-status-dependent changes in the $V_{\max }$ of $\left[{ }^{3} \mathrm{H}\right] 5-\mathrm{HT}$ in demented vs. non-demented subjects [41]. The observation that $A \beta_{40}$ reduces the baseline uptake rate of $\left[{ }^{3} \mathrm{H}\right] 5$-HT could explain the discrepant findings, since it demonstrates that the activity of SERT is specifically dependent on the levels of $A \beta_{40}$.

Although TNF, IL-1 $\beta$, and IL- 6 have been shown to regulate the density and function of the SERT, there was no evidence of a direct, cytokine-mediated mechanism for the decreased SERT-binding levels in the current study. The concentration of IL-6, which has been reported to reduce $\left[{ }^{3} \mathrm{H}\right] 5-\mathrm{HT}$ uptake, SERT mRNA, and SERT protein levels [23], was age-dependently increased in both $A P P_{\mathrm{swe}} / P S 1_{\mathrm{dE} 9}$ and WT animals. Similarly, there 
were no effects of genotype on the levels of TNF. The tissue concentration of IL-1 $\beta$, which was elevated over control in 12 -month-old $A P P_{\mathrm{swe}} / P S 1_{\mathrm{dEg}}$ mice, was not associated with increased uptake of $\left[{ }^{3} \mathrm{H}\right] 5-\mathrm{HT}$, as shown previously in mouse brain synaptosomes [22]. A prima facie case for the lack of cytokine-induced effects on the activity of SERT is that the levels of TNF, IL-1 $\beta$, and IL- 6 measured here in the aged TG brain were lower by at least an order of magnitude compared to the aforementioned in vitro studies. It might thus be that the interplay between pro-inflammatory cytokines and SERT function requires conditions of severe neuroinflammation, such as those encountered in murine models of experimental stroke, where the brain levels of IL-1 $\beta$ and TNF exceed those measured in 20-month-old $A P P_{\text {swe }} /$ $P S 1_{\mathrm{dE} 9}$ mice by $\sim 3-20$ times, respectively [42].

It is important to highlight three observations regarding the development of neuroinflammation in this study. First, the increased binding of $\left[{ }^{3} \mathrm{H}\right] \mathrm{PK} 11195$ in the WT mouse brain substantiates reports that TSPO imaging with this particular ligand is susceptible to the effects of aging [43]. Coupled with the age-dependent increase in the tissue concentration of TNF, IL- $1 \beta$, and IL- 6 , it is clear from the present data that advancing age constitutes a risk factor for pro-inflammatory processes in the mammalian brain. The increase in the protein levels of TNF and IL-1 $\beta$, in particular, is consistent with the physiological, age-associated upregulation of TNF and IL-1 $\beta$ RNA in murine microglia [44], the major source of these pro-inflammatory cytokines in the intact mouse and human brain [45]. Second, the increase in $\left[{ }^{3} \mathrm{H}\right] \mathrm{PK} 11195$-binding levels was more prominent in the neocortex of $A P P_{\text {swe }} / P S 1_{\mathrm{dE} 9}$ rather than WT mice, underlining the importance of amyloid status in TSPO imaging. Third, increased binding of $\left[{ }^{3} \mathrm{H}\right] \mathrm{PK} 11195$ in TG animals preceded the decline in markers of serotonergic integrity, indicating that monitoring TSPO levels may provide a useful indicator of the development of AD-related neuropathology. The inverse relationship between the binding levels of $\left[{ }^{3} \mathrm{H}\right] \mathrm{PK} 11195$ and $\left[{ }^{3} \mathrm{H}\right] \mathrm{DASB}$ in the parietal cortex, a brain region that has been shown to be particularly vulnerable in early-onset $\mathrm{AD}$ [46], supports this suggestion.

\section{Conclusions}

This study demonstrates that the progression of cerebral amyloidosis is associated with neuroinflammation and decreased presynaptic markers of serotonergic integrity and activity. The $\mathrm{A} \beta_{40}$-induced reduction in the uptake kinetics of $\left[{ }^{3} \mathrm{H}\right] 5$ - $\mathrm{HT}$ might explain some of the discrepancy in the antidepressant and cognitive effects of SSRI treatment in AD patients. Our observations imply that anti-amyloid therapies may prove more useful than
SSRIs in alleviating symptoms associated with serotonergic dysfunction in late-stage $\mathrm{AD}$.

\section{Abbreviations}

5-HT: Serotonin; AD: Alzheimer's disease; APP: Amyloid precursor protein; A $\beta$ : Amyloid- $\beta$; DASB: 3-Amino-4-(2-dimethylaminomethylphenylsulfanyl)benzonitrile; IL-1 $\beta$ : Interleukin-1 $\beta$; IL-6: Interleukin-6; $K_{m}$ : Michaelis constant; PK11195: 1-(2-Chlorophenyl)-N-methyl-N-(1-methylpropyl)-3-

isoquinolinecarboxamide; PSEN: Presenilin; SERT: Serotonin transporter; SSRIs: Selective Serotonin Reuptake Inhibitors; TG: Transgenic; TNF: Tumor necrosis factor; TSPO: Translocator protein; $V_{\text {max }}$ : Maximal velocity rate; WT: Wild-type

\section{Acknowledgements}

Not applicable.

\section{Funding}

This study was funded by the A.P. Møller og Hustru Chastine Mc-Kinney Møllers Fond (15-267) and the University of Southern Denmark (SDU2020, CoPING AD: Collaborative Project on the Interaction between Neurons and Glia in AD).

\section{Availability of data and materials}

All data generated or analyzed during this study are included in this published article. Raw data are available from the corresponding author on reasonable request.

\section{Authors' contributions}

AM designed the study and wrote the manuscript and performed the autoradiography, binding assays, and data analysis. MA performed the tissue sectioning, membrane isolation, autoradiography, binding assays, PCR, and data analysis. RV performed the tissue sectioning, autoradiography, and data analysis. SP performed the PCR and Meso Scale experiments. AML and BF supervised the project and contributed to its design. All authors assisted with the data interpretation, participated in drafting and critically reviewing of the manuscript, and approved its final version.

\section{Ethics approval}

All procedures were approved by the Danish Animal Ethics Inspectorate (nr 2011/561-1950) and complied with European Union directive 2010/63/EU, regulating animal research.

\section{Consent for publication}

Not applicable.

\section{Competing interests}

The authors declare that they have no competing interests.

\section{Publisher's Note}

Springer Nature remains neutral with regard to jurisdictional claims in published maps and institutional affiliations.

\section{Author details}

${ }^{1}$ Department of Neurobiology, Institute of Molecular Medicine, University of Southern Denmark, J.B. Winsløws Vej 25, DK-5000 Odense C, Denmark. ${ }^{2}$ Department of Nuclear Medicine \& PET Center, Aarhus University and Hospital, Nørrebrogade 44, Building 10G, DK-8000 Aarhus, Denmark.

${ }^{3}$ Translational Neuropsychiatry Unit, Department of Clinical Medicine, Aarhus University, Skovagervej 2, DK-8240 Risskov, Denmark.

Received: 25 February 2019 Accepted: 4 April 2019

Published online: 01 May 2019

\section{References}

1. Banerjee S, Hellier J, Dewey M, Romeo R, Ballard C, Baldwin R, et al. Sertraline or mirtazapine for depression in dementia (HTA-SADD): a randomised, multicentre, double-blind, placebo-controlled trial. Lancet. 2011;378(9789):403-11.

2. Moraros J, Nwankwo C, Patten SB, Mousseau DD. The association of antidepressant drug usage with cognitive impairment or dementia, 
including Alzheimer disease: a systematic review and meta-analysis. Depress Anxiety. 2017;34(3):217-26.

3. Bartels C, Wagner M, Wolfsgruber S, Ehrenreich H, Schneider A. Alzheimer's disease neuroimaging I. Impact of SSRI therapy on risk of conversion from mild cognitive impairment to Alzheimer's dementia in individuals with previous depression. Am J Psychiatry. 2018;175(3):232-41.

4. Ma J, Gao Y, Jiang L, Chao FL, Huang W, Zhou CN, et al. Fluoxetine attenuates the impairment of spatial learning ability and prevents neuron loss in middle-aged APPswe/PSEN1dE9 double transgenic Alzheimer's disease mice. Oncotarget. 2017:8(17):27676-92.

5. Nelson RL, Guo Z, Halagappa VM, Pearson M, Gray AJ, Matsuoka Y, et al. Prophylactic treatment with paroxetine ameliorates behavioral deficits and retards the development of amyloid and tau pathologies in 3xTgAD mice. Exp Neurol. 2007;205(1):166-76.

6. Severino M, Sivasaravanaparan M, Olesen LO, von Linstow CU, Metaxas A, Bouzinova EV, et al. Established amyloid-beta pathology is unaffected by chronic treatment with the selective serotonin reuptake inhibitor paroxetine. Alzheimers Dement (N Y). 2018;4:215-23.

7. Sierksma AS, de Nijs L, Hoogland G, Vanmierlo T, van Leeuwen FW, Rutten $\mathrm{BP}$, et al. Fluoxetine treatment induces seizure behavior and premature death in APPswe/PS1dE9 mice. J Alzheimers Dis. 2016;51(3):677-82.

8. Benarroch EE. Monoamine transporters: structure, regulation, and clinical implications. Neurology. 2013;81(8):761-8.

9. Holm P, Ettrup A, Klein AB, Santini MA, El-Sayed M, Elvang AB, et al. Plaque deposition dependent decrease in 5-HT2A serotonin receptor in AbetaPPswe/PS1dE9 amyloid overexpressing mice. J Alzheimers Dis. 2010; 20(4):1201-13.

10. Jankowsky JL, Slunt HH, Ratovitski T, Jenkins NA, Copeland NG, Borchelt DR. Co-expression of multiple transgenes in mouse CNS: a comparison of strategies. Biomol Eng. 2001;17(6):157-65.

11. Noristani HN, Meadows RS, Olabarria M, Verkhratsky A, Rodriguez JJ. Increased hippocampal CA1 density of serotonergic terminals in a triple transgenic mouse model of Alzheimer's disease: an ultrastructural study. Cell Death Dis. 2011;2:e210.

12. Noristani HN, Olabarria M, Verkhratsky A, Rodriguez JJ. Serotonin fibre sprouting and increase in serotonin transporter immunoreactivity in the CA1 area of hippocampus in a triple transgenic mouse model of Alzheimer's disease. Eur J Neurosci. 2010:32(1):71-9.

13. Von Linstow CU, Severino M, Metaxas A, Waider J, Babcock AA, Lesch KP, et al. Effect of aging and Alzheimer's disease-like pathology on brain monoamines in mice. Neurochem Int. 2017;108:238-45.

14. Liu Y, Yoo MJ, Savonenko A, Stirling W, Price DL, Borchelt DR, et al. Amyloid pathology is associated with progressive monoaminergic neurodegeneration in a transgenic mouse model of Alzheimer's disease. J Neurosci. 2008;28(51):13805-14.

15. Trillo L, Das D, Hsieh W, Medina B, Moghadam S, Lin B, et al. Ascending monoaminergic systems alterations in Alzheimer's disease. Translating basic science into clinical care. Neurosci Biobehav Rev. 2013;37(8):1363-79.

16. Heneka MT, Carson MJ, El Khoury J, Landreth GE, Brosseron F, Feinstein DL, et al. Neuroinflammation in Alzheimer's disease. Lancet Neurol. 2015;14(4): 388-405.

17. Janssen B, Vugts DJ, Funke U, Molenaar GT, Kruijer PS, van Berckel BN, et al. Imaging of neuroinflammation in Alzheimer's disease, multiple sclerosis and stroke: recent developments in positron emission tomography. Biochim Biophys Acta. 2016;1862(3):425-41.

18. Babcock AA, Ilkjaer L, Clausen BH, Villadsen B, Dissing-Olesen L, Bendixen AT, et al. Cytokine-producing microglia have an altered beta-amyloid load in aged APP/PS1 Tg mice. Brain Behav Immun. 2015;48:86-101.

19. Hickman SE, Allison EK, El Khoury J. Microglial dysfunction and defective beta-amyloid clearance pathways in aging Alzheimer's disease mice. J Neurosci. 2008;28(33):8354-60.

20. Swardfager W, Lanctot K, Rothenburg L, Wong A, Cappell J, Herrmann N. A meta-analysis of cytokines in Alzheimer's disease. Biol Psychiatry. 2010; 68(10):930-41.

21. Zhu CB, Lindler KM, Owens AW, Daws LC, Blakely RD, Hewlett WA. Interleukin-1 receptor activation by systemic lipopolysaccharide induces behavioral despair linked to MAPK regulation of CNS serotonin transporters. Neuropsychopharmacol. 2010;35(13):2510-20.

22. Zhu CB, Blakely RD, Hewlett WA. The proinflammatory cytokines interleukin1 beta and tumor necrosis factor-alpha activate serotonin transporters. Neuropsychopharmacol. 2006;31(10):2121-31.
23. Kong E, Sucic S, Monje FJ, Savalli G, Diao W, Khan D, et al. STAT3 controls IL6-dependent regulation of serotonin transporter function and depressionlike behavior. Sci Rep. 2015;5:9009.

24. Metaxas A, Vaitheeswaran R, Jensen KT, Thygesen C, Ilkjaer L, Darvesh S, et al. Reduced serotonin transporter levels and inflammation in the midbrain raphe of 12 month old APPswe/PSEN1dE9 mice. Curr Alzheimer Res. 2018; 15(5):420-8.

25. Owen DR, Howell OW, Tang SP, Wells LA, Bennacef I, Bergstrom M, et al. Two binding sites for [3H]PBR28 in human brain: implications for TSPO PET imaging of neuroinflammation. J Cereb Blood Flow Metab. 2010;30(9):1608-18.

26. Allen Institute for Brain Science @ 2004. Allen Mouse Brain Atlas. Available from: http://mouse.brain-map.org.

27. Grebing $M$, Nielsen $H H$, Fenger $C D, K T$, von Linstow $C U$, Clausen $B H$, et al. Myelin-specific T cells induce interleukin-1 beta expression in lesion-reactive microglial-like cells in zones of axonal degeneration. Glia. 2016;64(3):407-24.

28. Azmitia EC, Nixon R. Dystrophic serotonergic axons in neurodegenerative diseases. Brain Res. 2008;1217:185-94.

29. D'Amato RJ, Zweig RM, Whitehouse PJ, Wenk GL, Singer HS, Mayeux R, et al. Aminergic systems in Alzheimer's disease and Parkinson's disease. Ann Neurol. 1987:22(2):229-36.

30. Thomas AJ, Hendriksen M, Piggott M, Ferrier IN, Perry E, Ince P, et al. A study of the serotonin transporter in the prefrontal cortex in late-life depression and Alzheimer's disease with and without depression. Neuropathol Appl Neurobiol. 2006;32(3):296-303.

31. Marner L, Frokjaer VG, Kalbitzer J, Lehel S, Madsen K, Baare WF, et al. Loss of serotonin $2 \mathrm{~A}$ receptors exceeds loss of serotonergic projections in early Alzheimer'[s disease: a combined [11C] DASB and [18F]altanserin-PET study. Neurobiol Aging 2012;33(3):479-487.

32. Smith GS, Barrett FS, Joo JH, Nassery N, Savonenko A, Sodums DJ, et al. Molecular imaging of serotonin degeneration in mild cognitive impairment. Neurobiol Dis. 2017;105:33-41.

33. Bowen DM, Allen SJ, Benton JS, Goodhardt MJ, Haan EA, Palmer AM, et al. Biochemical assessment of serotonergic and cholinergic dysfunction and cerebral atrophy in Alzheimer's disease. J Neurochem. 1983;41(1):266-72.

34. Palmer AM, Francis PT, Benton JS, Sims NR, Mann DM, Neary D, et al. Presynaptic serotonergic dysfunction in patients with Alzheimer's disease. J Neurochem. 1987:48(1):8-15.

35. Cirrito JR, Disabato BM, Restivo JL, Verges DK, Goebel WD, Sathyan A, et al. Serotonin signaling is associated with lower amyloid-beta levels and plaques in transgenic mice and humans. Proc Natl Acad Sci U S A. 2011; 108(36):14968-73.

36. Sheline YI, West T, Yarasheski K, Swarm R, Jasielec MS, Fisher JR, et al. An antidepressant decreases CSF Abeta production in healthy individuals and in transgenic AD mice. Sci Transl Med. 2014;6(236):236re4.

37. Emilsson JF, Andreasson U, Blennow K, Eriksson E, Zetterberg $\mathrm{H}$. Comment on "An antidepressant decreases CSF Abeta production in healthy individuals and in transgenic AD mice". Sci Transl Med. 2014; 6(268):268le5.

38. von Linstow CU, Waider J, Grebing M, Metaxas A, Lesch KP, Finsen B. Serotonin augmentation therapy by escitalopram has minimal effects on amyloid-beta levels in early-stage Alzheimer's-like disease in mice. Alzheimers Res Ther. 2017;9(1):74

39. Inestrosa NC, Alarcon R, Arriagada J, Donoso A, Alvarez J. Platelet of Alzheimer patients: increased counts and subnormal uptake and accumulation of [14C]5-hydroxytryptamine. Neurosci Lett. 1993; 163(1):8-10.

40. Koren P, Diver-Haber A, Adunsky A, Rabinowitz M, Hershkowitz M. Uptake of serotonin into platelets of senile dementia of the Alzheimer type patients. J Gerontol. 1993:48(3):B93-6.

41. Arora RC, Emery OB, Meltzer HY. Serotonin uptake in the blood platelets of Alzheimer's disease patients. Neurology. 1991;41(8):1307-9.

42. Gronhoj MH, Clausen BH, Fenger CD, Lambertsen KL, Finsen B. Beneficial potential of intravenously administered IL-6 in improving outcome after murine experimental stroke. Brain Behav Immun. 2017;65:296-311.

43. Kumar A, Muzik O, Shandal V, Chugani D, Chakraborty P, Chugani HT. Evaluation of age-related changes in translocator protein (TSPO) in human brain using (11) C-[R]-PK11195 PET. J Neuroinflammation. 2012;9:232.

44. Hickman SE, Kingery ND, Ohsumi TK, Borowsky ML, Wang LC, Means TK, et al. The microglial sensome revealed by direct RNA sequencing. Nat Neurosci. 2013;16(12):1896-905. 
45. Galatro TF, Holtman IR, Lerario AM, Vainchtein ID, Brouwer N, Sola PR, et al. Transcriptomic analysis of purified human cortical microglia reveals ageassociated changes. Nat Neurosci. 2017;20(8):1162-71.

46. Ossenkoppele R, Zwan MD, Tolboom N, van Assema DM, Adriaanse SF,

Kloet RW, et al. Amyloid burden and metabolic function in early-onset

Alzheimer's disease: parietal lobe involvement. Brain. 2012;135(Pt 7:2115-25.

Ready to submit your research? Choose BMC and benefit from:

- fast, convenient online submission

- thorough peer review by experienced researchers in your field

- rapid publication on acceptance

- support for research data, including large and complex data types

- gold Open Access which fosters wider collaboration and increased citations

- maximum visibility for your research: over $100 \mathrm{M}$ website views per year

At $B M C$, research is always in progress.

Learn more biomedcentral.com/submissions 